\title{
PENGARUH RESPONSIBILITAS DAN SIKAP KERJA TERHADAP KUALITAS PELAYANAN DI KELURAHAN TENGAH KECAMATAN CIBINONG KABUPATEN BOGOR
}

\author{
A.H. Rahadian dan Bambang Rusantono \\ Institut Ilmu Sosial dan Manajemen STIAMI \\ rahadian_ah@yahoo.com
}

ABSTRACT. The problem that made the object of research is the phenomenon of the Quality of Service in Tengah Sub-District at Cibinong District in Bogor Regency is not optimal. The purpose of this study is that analyze the magnitude Influence Responsibility and Work Attitude toward the Quality of Service in Tengah Sub-District at Cibinong District in Bogor Regency.

This study uses a quantitative explanatory to saw how much influence $X_{1}$ and $X_{2}$ to $Y$ by partial and multiple. Population in this research service recipient in Tengah Sub-District amounted to 1.332 people and sampling by Slovin, the samples are 308 respondents. The research instrument using a Likert scale.

Results of the analysis and discussion of the results showed that There is a Significant and Positive Influence of Responsibility toward the Quality of Service in Tengah Sub-District at Cibinong District in Bogor Regency; There is a Significant and Positive Influence of Work Attitude toward the Quality of Service in Tengah Sub-District at Cibinong District in Bogor Regency; and There is a Significant and Positive Influence of Responsibility and Work Attitude together toward the Quality of Service in Tengah Sub-District at Cibinong District in Bogor Regency.

Keywords: Responsibility, Work Attitude, and Quality of Service

ABSTRAK. Masalah yang dijadikan obyek penelitian adalah fenomena Kualitas Pelayanan di Kelurahan Tengah Kecamatan Cibinong Kabupaten Bogor yang belum optimal. Tujuan penelitian ini adalah untuk manganalisis besarnya Responsibilitas dan Sikap Kerja terhadap Kualitas Pelayanan di Kelurahan Tengah Kecamatan Cibinong Kabupaten Bogor.

Penelitian ini menggunakan metode explanatory kuantitatif untuk melihat seberapa besar pengaruh $\mathrm{X}_{1}$ dan $\mathrm{X}_{2}$ terhadap $\mathrm{Y}$ secara parsial dan berganda. Populasi dalam penelitian ini penerima layanan di Kelurahan Tengah berjumlah 1.332 orang dan pengambilan sampel dengan Slovin maka sampel penelitian sebanyak 308 responden. Instrumen penelitian menggunakan skala likert.

Hasil analisis dan pembahasan hasil penelitian menunjukkan bahwa Terdapat Pengaruh Positif dan Signifikan Responsibilitas terhadap Kualitas Pelayanan di Kelurahan Tengah Kecamatan Cibinong Kabupaten Bogor; Terdapat Pengaruh Positif dan Signifikan Sikap Kerja terhadap Kualitas Pelayanan di Kelurahan Tengah Kecamatan Cibinong Kabupaten Bogor; dan Terdapat Pengaruh Positif dan Signifikan Responsibilitas dan Sikap Kerja secara bersama-sama terhadap Kualitas Pelayanan di Kelurahan Tengah Kecamatan Cibinong Kabupaten Bogor.

Kata Kunci: Responsibilitas, Sikap Kerja, dan Kualitas Pelayanan

Undang-undang Nomor 32 tahun 2004 tentang Pemerintahan Daerah menempatkan kelurahan tidak lagi sebagai perangkat kecamatan, akan tetapi berkedudukan sebagai perangkat daerah sebagaimana unit kerja lainnya yang secara administrasi lingkup wilayahnya berada dalam wilayah kecamatan. Kelurahan tidak lagi menerima limpahan kewenangan dari camat, tetapi menerima pelimpahan sebagian urusan otonomi daerah dari Bupati. Pegawai kelurahan pun dalam konteks undang-undang ini otomatis merupakan pegawai daerah. Sementara itu, hubungan antara kelurahan dan kecamatan lebih bersifat koordinasi dan fasilitasi, bukan hirarki.

Untuk itu Kelurahan Tengah Kabupaten Bogor berdasarkan Peraturan Pemerintah Nomor 73 Tahun 2005 tentang Kelurahan menjelaskan bahwa Kelurahan yang bertanggungjawab kepada Bupati melalui Camat sebagai tugas perbantuan dalam 
pelaksanaan pemerintahan, pembangunan, sosial kemasyarakatan dan pemberdayaan masyarakat, pelayanan masyarakat, penyelenggaraan ketenteraman dan ketertiban umum, pemeliharaan prasarana dan memelihara fasilitas pelayanan umum.

Berdasarkan kebijakan tentang kelurahan tidak hanya memberi peluang yang seluas-luasnya kepada pemerintah kelurahan untuk mengoptimalisasikan pelaksanaan kebijakan desentralisasi dan otonomi daerah bagi meningkatnya kesejahteraan masyarakat, tetapi sekaligus juga menyodorkan sejumlah tantangan organisasi dan manajemen pemerintahan yang menuntut kesiapan sumber daya aparatur tetapi sekaligus juga menuntut suatu sistem pengorganisasian satuan kerja perangkat daerah yang efektif dan efisien. Efektif menunjukkan seluruh satuan kerja perangkat daerah dapat mencapai tujuan dan sasaran pelaksanaan fungsi-fungsi pemerintahan seperti fungsi pembangunan, fungsi pelayanan dan fungsi pemberdayaan yang bertujuan untuk mensejahterakan masyarakat.

Efisiensi adalah urusan pemerintahan yang dilimpahkan dalam penanggannya dipastikan lebih berdaya guna dan berhasil guna dilaksanakan oleh kelutahan dibandingkan jika ditangani oleh perangkat daerah lainnya. Sedangkan peningkatan akuntabilitas urusan pemerinahan yang dilimpahkan kepada kelurahan lebih langsung/dekat dan berdampak/berakibat kepada masyarakat karena mampu menyentuh aspirasi masyarakat (bottom up).

Namun, pelaksanaan tugas dan tanggung jawab yang menjadi tanggung jawab Kelurahan Tengah Kecamatan Cibinong yang sedemikian itu tidak lah mudah, karena faktor wilayah, kondisi dan karakteristik setiap daerah sangat berbeda, baik potensi penduduk maupun potensi alam untuk mendukung keberhasilan gerak pembangunan yang menjadi skala pogram prioritas Pemerintahan Kabupaten Bogor. Kelurahan Tengah yang dituntut untuk dapat menyelaraskan gerak pembangunan dengan bebagai kesiapan sumber daya seperti sumber daya aparatur, anggaran, dukungan organisasi serta partisipasi masyarakat, terutama dalam melaksanakan pelayanan publik yang berkualitas.

Hal ini menunjukkan bahwa Kelurahan Tengah sebagai garda terdepan harus mampu menyelaraskan Visi dan Misi Pemerintah Kabupaten Bogor dengan menterpadukan dan mengakomodasi tuntutan publik dalam suatu kegiatan program kerja Kelurahan Tengah melalui semangat pelayanan dan pertanggung jawaban publik. Selain itu serta integritas pengabdian dalam mewujudkan cita-cita dan tujuan pemerintah dalam mensejahterakan masyarakat menjadi prioritas utama Kelurahan Tengah untuk menyikapi tuntutan kualitas pelayanan publik dalam penyelenggaraan pemerintah di kelurahan harus mampu memperbaiki konsep pelayanan yang efektif dan transfaran dalam konteks memberikan pelayanan kepada masyarakat baik di bidang pembangunan, pemberdayaan masyarakat, dan kesehatan dengan tujuan mewujudkan kesejahteraan masyarakat.

Selain itu, kualitas pelayanan di Kelurahan Tengah juga dituntut untuk mengupayakan peningkatan kesejahteraan masyarakat yang ditunjukkan pada empat indikator keberhasilan pembangunan yaitu adanya pertumbuhan, mengurangi pengangguran, mengurangi kemiskinan, dan meningkatkan pendapatan masyarakat dengan memberdayakan berbagai sumber daya yang ada di wilayah Kelurahan Tengah Kecamatan Cibinong.

Namun pelaksanaan pelayanan publik di Kelurahan Tengah kurang sesuai harapan, hal ini karena:

1. Proses pelayanan yang kurang cepat dan masih berbelit-belit.

2. Keluhan masyarakat terkait dengan tingkat disiplin dan perilaku petugas layanan yang harus lama menunggu kedatangan petugas pelayanan dan ketika dibutuhkan petugas pelayanan sering tidak siap di tempat.

3. Keluhan masyarakat penerima layanan perizinan yang berkaitan dengan cara dan proses pemberian layanan oleh petugas teknis pelayanan yang sering bersikap kurang direspon dengan baik. 
4. Masih adanya ketentuan biaya pengurusan seperti pindah alamat KTP yang dikenakan kepada masyarakat yang pindah ke daerah lain.

5. Jaminan layanan administrasi kependudukan yang kurang sesuai dengan waktu yang ditentukan.

6. Kehandalan pegawai dalam mendukung kegiatan pelayanan yang masih kurang sesuai harapan.

Dalam konteks itu, karena kurangnya pelayanan yang disajikan aparatur kelurahan dalam mendukung kualitas pelayanan publik sesuai dengan Undang-undang Nomor 25 tahun 2009 tentang Pelayanan Publik. Permasalahan tersebut diduga karena responsibilitas pelaksanaan tugas dan fungsi oleh aparatur Kelurahan Tengah. Respon aparatur dalam menjalankan tugas dan tanggungjawab masih kurang menunjukkan perilaku yang positif, sehingga menimbulkan sejumlah kelemahan responsibilitas dalam melayani masyarakat dan responsibilitas pada inisiatif kerja aparatur belum dapat menunjukkan kontribusi bagi sejumlah hasil pelayanan kepada masyarakat. Faktor ini berakibat hasil kerja aparatur kurang optimal.

Hal ini menunjukkan bahwa responsibilitas berpengaruh terhadap kualitas pelayanan di Kelurahan Tengah Kecamatan Cibinong Kabupaten Bogor. Permasalahan yang menunjukkan keterpengaruhan kualitas pelayanan, dinyatakan oleh Pribadi, et al. (2014) dan Ahmad (2013) bahwa Responsibilitas berpengaruh positif dan signifikan terhadap kualitas pelayanan publik.

Selain itu sikap kerja aparatur Kelurahan Tengah masih dipengaruhi pada sikap birokrasi sehingga kurang memenuhi asas pelayanan pemerintah yang menjelaskan bahwa masyarakat sebagai pelanggan yang harus dilayani dengan baik. Selain itu, sikap kerja aparatur kurang sesuai harapan dalam praktek penyelenggaraan pemerintahan khususnya pelaksanaan tugas pelayanan yang seharusnya cepat, tanggap, dan tidak berbelitbelit. Sikap kerja aparatur masih ditunjukkan sebagai birokrat pemerintah yang kurang mampu menunjukkan empati pada penerima layanan.
Hal ini menunjukkan bahwa Sikap Kerja berpengaruh terhadap kualitas pelayanan di Kelurahan Tengah Kecamatan Cibinong Kabupaten Bogor. Permasalahan yang menunjukkan keterpengaruhan kualitas pelayanan, dinyatakan oleh Hidayati (Tesis:2011) bahwa Sikap berpengaruh cukup kuat, positif dan signifikan terhadap kualitas pelayanan.

Permasalahan kurangnya dukungan Responsibilitas dan Sikap Kerja dalam menjalankan tugas dan tanggungjawab pegawai di Kelurahan Tengah belum dapat memenuhi capaian pelayanan yang ditargetkan Kelurahan Tengah berdasarkan capaian hasil dan capaian waktu penyelesaian pelayanan. Selain itu, kurangnya responsibilitas pada pekerjaan dan sikap kerja berakibat pada efisiensi aparatur kecamatan pada pemanfaatan alokasi anggaran dalam menjalankan tugas dan tanggungjawab belum dapat memenuhi capaian-capaian yang ditargetkan program kegiatan di kelurahan.

Dalam konteks itu, Kualitas Pelayanan di Kelurahan Tengah Kecamatan Cibinong Kabupaten Bogor tampak menjadi suatu fenomena capaian keberhasilan Pemerintah Kelurahan dalam melaksanakan fungsi pelayanan publik di Kelurahan Tengah. Selanjutnya, peneliti akan melakukan penelitian dengan judul "Pengaruh Responsibilitas dan Sikap Kerja terhadap Kualitas Pelayanan di Kelurahan Tengah Kecamatan Cibinong Kabupaten Bogor".

\section{Rumusan Masalah}

rumusan masalah dalam penelitian ini penulis ajukan dengan pertanyaan penelitian berikut:

1. Seberapa besar pengaruh Responsibilitas terhadap Kualitas Pelayanan di Kelurahan Tengah Kecamatan Cibinong Kabupaten Bogor?

2. Seberapa besar pengaruh Sikap Kerja terhadap Kualitas Pelayanan di Kelurahan Tengah Kecamatan Cibinong Kabupaten Bogor?

3. Seberapa besar pengaruh Responsibilitas dan Sikap kerja secara bersama-sama terhadap Kualitas Pelayanan di Kelurahan Tengah Kecamatan Cibinong Kabupaten Bogor? 


\section{Manfaat Penelitian}

\section{Manfaat Praktis}

Manfaat praktis untuk para pihak, terutama pimpinan Kelurahan Tengah Kecamatan Cibinong Kabupaten Bogor, hasil penelitian yang akan disusun menjadi suatu rekomendasi dapat dijadikan masukan yang berguna untuk meningkatkan Responsibilitas, Sikap Kerja, dan Kualitas Pelayanan di Kelurahan Tengah Kecamatan Cibinong Kabupaten Bogor.

2. Manfaat Akademis

Manfaat akademis yang diharapkan adalah bahwa hasil penelitian dapat dijadikan rujukan bagi upaya pemahaman ilmu Ilmu Administrasi Publik baik secara teoritis maupun praktek, dan berguna juga untuk menjadi referensi bagi mahasiswa yang melakukan kajian atas permasalahan Kualitas Pelayanan di Kelurahan Tengah Kecamatan Cibinong Kabupaten Bogor yang dipengaruhi oleh Responsibilitas dan Sikap Kerja.

\section{KAJIAN LITERATUR}

\section{Responsibilitas}

Menurut Ndraha (2003: 87) menyebutkan Responsibility (tanggung jawab) berasal dari akar kata latin respons (us). Lebih jauh Ndraha (2003: 87) menjelaskan bahwa tanggung jawab merupakan salah satu mata rantai, dan mata rantai terpenting, yang berhubungan dengan perintah, janji (commitment), dan status, dengan percaya dalam hubungan pemerintahan.

Sejalan dengan di atas, Dwiyanto (2006:50) menyebutkan tentang responsibilitas, adalah: Responsibilitas menjelaskan apakah pelaksanaan kegiatan organisasi publik itu dilakukan sesuai dengan prinsip-prinsip administrasi yang benar atau sesuai dengan kebijakan organisasi, baik yang eksplisit maupun implisit. Oleh sebab itu, responsibilitas bisa saja pada suatu ketika berbenturan dengan responsivitas.

Pengertian responsibilitas merupakan tanggung jawab birokrasi publik dalam melaksanakan tugas pelayanan yang berhubungan dengan pelayanan kebutuhan publik. Responsibilitas (tanggung jawab) adalah tanggung jawab seseorang terhadap tugas-tugasnya yang berhubungan dengan perannya sebagai pelaksana tugas pelayanan kepada pihak yang dilayani

Responsibilitas sangat penting dalam pelaksanaan tugas pokok seorang pegawai. Menurut Spiro (dalam Ndraha, 2003: 87), responsibility atau responsibilitas dapat diartikan sebagai accountability (perhitungan), sebagai obligation (kewajiban), dan sebagai cause (penggerak, acts) yang dijelaskan: (1) Accountability (perhitungan), Menunjukkan sejauh mana seorang pelaku pemerintahan terbukti mampu menjalankan tugas dan perintah yang diamanatkan kepadanya, menurut cara, alat, dan tingkat pencapaian sasaran yang telah ditetapkan, dari persolan ia menyetuji perintah itu atau ia merasa terpaksa, dipaksa harus, atau karena tiada pilihan, dan dalam pada itu ia harus menerima risikonya. (2) Obligation

(kewajiban), Menunjukkan sejauh mana seorang pelaku pemerintahan menepati, menunaikan, dan memenuhi janji (pledge, commitment, sense of duty, lahir dari kesepakatan) nya pada suatu saat, sedia menunaikan kewajiban-kewajiban yang lahir atau akibat dari status (kedudukan, posisi) sebagai pemerintah, dan sejauh mana ia bersedia memikul sanksi dan resikonya. (3) Causativveness (penggerak, acts), Menunjukkan sejauh mana tingkat keperdulian yang menggerakkan seorang pelaku pemerintahan, terlepas dari (tinggirendah) statusnya atau jabatannya, untuk bertindak atas inisiatif sendiri.

Sintesis renponsibilitas merupakan pertanggung jawaban seorang pegawai dalam melaksanakan tugas sesuai dengan tingkat kesesuaian antara penyelenggaraan pemerintahan dengan hukum atau peraturan dan prosedur yang telah ditetapkan.

\section{Sikap Kerja}

Kreitner dan Kinicki (dalam Wibowo, 2013: 49) mendefinisikan Sikap atau attitude sebagai suatu kecenderungan yang dipelajari untuk merespon dengan cara menyenangkan secara konsisten berkenaan dengan objek tertentu. Penjelasan ini mengartikan bahwa 


\section{A.H. Rahadian dan Bambang Rusantono, Pengaruh Responsibilitas dan Sikap .....}

sikap adalah respon seseorang pada suatu kejadian yang menyenangkan atau tidak.

Menurut Rivai dan Mulyadi (2012: 246) mengemukakan adanya tiga sikap yang mempengaruhi terhadap pekerjaan, sebagai berikut: (1) Kepuasan kerja (job satisfaction) merujuk pada sikap umum seseorang individu terhadap pekerjaannya. (2) Keterlibatan kerja (job involment) yang mengukur derajat sejauhmana seseorang memihak secara psikologis pada pekerjaannya dan menganggap tingkat kinerjanya yang dipresepsikan sebagai penting untuk harga diri. (3) Komitmen pada organisasi. Itu didefinisikan sebagai suatu keadaan di mana seseorang memihak pada suatu organisasi tertentu dan tujuan-tujuannya, serta berniat memeliharan keanggotan dalam organisasi itu.

Penjelasan di atas dapat disimpulkan bahwa sikap seseorang akan mempengaruhi pada aktivitas kerja baik secara kualitas maupun kuantitas karena secara sikologis sikap akan merujuk pada kinerja seseorang.

Menurut Robbins (2006: 93) mengemukakan adanya 3 komponen sikap, yaitu: (1) Komponen Kognitif Sikap, Segmen pendapat atau keyakinan dari sikap. (2) Komponen Afektif Sikap, Segmen emosional atau perasan dari sikap. (3) Komponen Perilaku Sikap, Maksud untuk berperilaku dalam cara tertentu terhadap seseorang atau sesuatu.

Dengan demikian sikap akan membentuk perilaku seseorang dalam melaksanakan berbagai aktivitas kegiatan yang menimbulkan reaksi tertentu yang bersifat efektif, kognitif, atau behavioral.

\section{Kualitas Pelayanan}

Menurut Sinambela (2008:6) jika dihubungkan dengan administrasi publik, pelayanan adalah kualitas pelayanan birokrat

\section{METODE PENELITIAN}

\section{Pendekatan Penelitian}

Pendekatan Penelitian ini kuantitatif dengan menggunakan deskriptif analitik dan bersifat explanatory, yaitu menganalisa gejala terhadap masyarakat. Selanjutnya, Crosby et al., (dalam Achmad, 2011:180) mengartikan kualitas pelayanan publik adalah: Kualitas pelayanan merupakan perincian-perincian (conformance of specification), di mana kualitas dipandang sebagai derajat keunggulan yang ingin dicapai, dilakukannya kontrol terus menerus dalam mencapai keunggulan.

Berdasarkan teori Servqual, yang berangkat dari kesepuluh dimensi itu, mempunyai lima dimensi yang mewakili kesepuluh kriteria tersebut. Menurut Zeithaml, Parasuraman dan Berry (dalam Ratminto dan Atik, 2010: 175) menjelaskan sebagai berikut: (1) Tangibles atau ketampakan fisik, artinya petampakan fisik dari gedung, peralatan, pegawai, dan fasilitasfasilitas lain yang dimiliki oleh providers. (2) Reliability atau reliabilitas adalah kemampuan untuk menyelenggarakan pelayanan yang dijanjikan secara akurat. (3) Responsiveness atau responsivitas adalah kerelaan untuk menolong customers dan menyelenggarakan pelayanan secara ikhlas. (4) Assurance atau kepastian adalah pengetahuan dan kesopanan para pekerja dan kemampuan mereka dalam memberikan kepercayaan kepada customers. (5) Emphaty adalah perlakuan atau perhatian pribadi yang diberikan oleh providers kepada customers.

Sintesis kualitas pelayanan publik adalah tanggung jawab pemerintah atas kegiatan yang ditujukan untuk kepentingan umum dan masyarakat yang mengandung adanya unsur-unsur perhatian dan kesediaan serta kesiapan dari pelaksanan pelayanan tersebut, serta didukung oleh aparatur pemerintah yang ditunjukkan dari keterampilan atau keahlian dan semangat yang tinggi sebagai pelayan publik, sehingga pelayanan dapat secara maksimal diterima dan memberikan kepuasan bagi masyara pengaruh antara dua variabel atau lebih. Metode survei dalam penelitian ini bertujuan memberikan gambaran tentang masingmasing variabel dengan cara menganalisis pengaruh variabel bebas terhadap variabel terikat. Pola pengaruh yang akan dikaji dipresentasikan pada gambar berikut : 


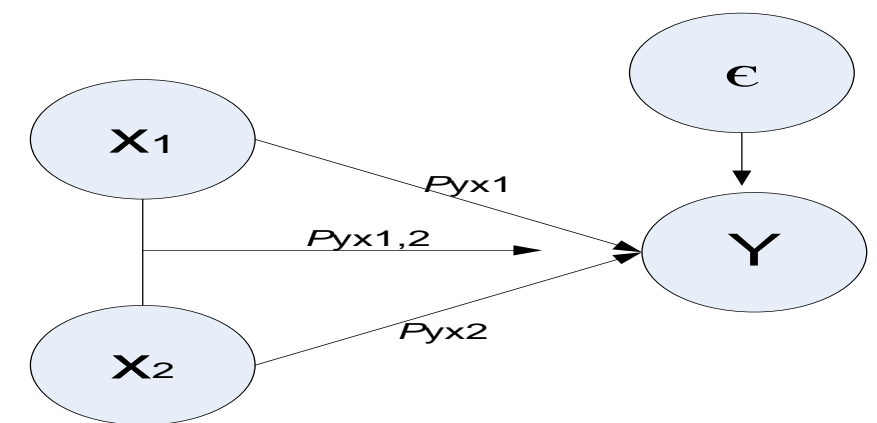

Gambar 1 Model Penelitian

Keterangan :

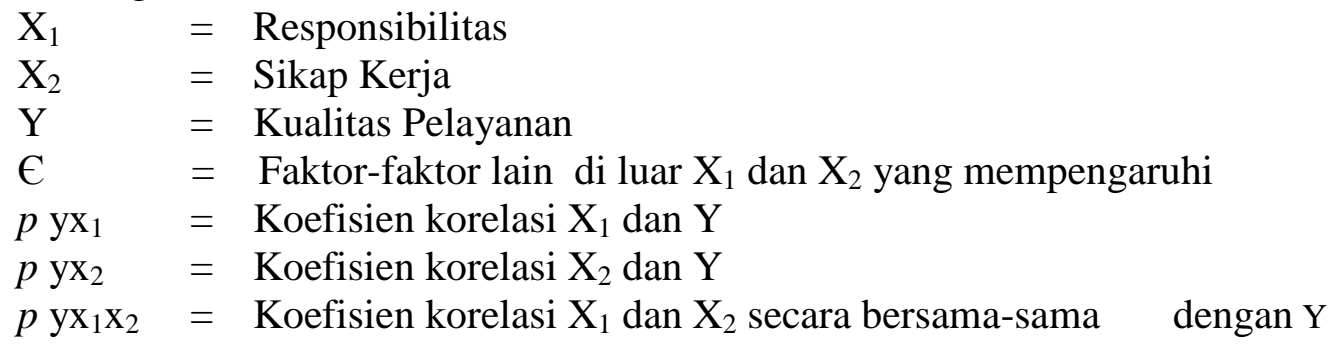

\section{Operasionalisasi Variabel Penelitian}

Operasionalisasi variabel variabel Kualitas Pelayanan terlihat pada tabel kisi-kisi operasional variabel di bawah ini:

Responsibilitas, variabel Sikap Kerja, dan

Tabel 1 Kisi-kisi Operasional Variabel Penelitian

\begin{tabular}{|c|c|c|c|c|}
\hline Rujukan Teori & Variabel & Dimensi & Indikator & Item \\
\hline $\begin{array}{c}\text { Spiro dalam } \\
\text { Ndraha, 2003: } \\
87\end{array}$ & $\begin{array}{c}\text { Responsibilitas } \\
\text { X1 }\end{array}$ & $\begin{array}{l}\text { 1. Accountability } \\
\text { (Akuntabilitas) } \\
\text { 2. Obligativeness } \\
\text { (Kewajiban) }\end{array}$ & $\begin{array}{ll}\text { 1.1 } & \text { Reward \& punishment } \\
\text { 1.2 } & \text { Pengalaman kerja } \\
\text { 1.3 } & \text { Kepatuhan jam kerja } \\
\text { 1.4 } & \text { Kepatuhan SOP } \\
\text { 1.5 } & \text { Tanggungjawa kerja. } \\
& \\
\text { 1.1 } & \text { Pelaksanaan perintah } \\
\text { 1.2 } & \text { Status kerja } \\
\text { 1.3 } & \text { Pengabdian kerja } \\
\text { 1.4 } & \text { Konsistensi kerja } \\
\text { 1.5 } & \text { Kebersamaan } \\
\text { 2.1 } & \text { Loyalitas } \\
\text { 2.2 } & \text { Semangat kerja } \\
\text { 2.3 } & \text { Perilaku kerja } \\
\text { 2.4 } & \text { Interaksi } \\
\text { 2.5 } & \text { Aktivitas kerja }\end{array}$ & $\begin{array}{l}1 \\
2 \\
3 \\
4 \\
5 \\
\\
6 \\
7 \\
8 \\
9 \\
10 \\
\\
11 \\
12 \\
13 \\
14 \\
15\end{array}$ \\
\hline
\end{tabular}


A.H. Rahadian dan Bambang Rusantono, Pengaruh Responsibilitas dan Sikap

\begin{tabular}{|c|c|c|c|c|}
\hline Rujukan Teori & Variabel & Dimensi & Indikator & Item \\
\hline $\begin{array}{l}\text { Robbins } \\
\text { (2006: 93) }\end{array}$ & Sikap Kerja & $\begin{array}{l}\text { 1. Kognitif } \\
\text { 2. Afektif } \\
\text { 3. Behavioral }\end{array}$ & $\begin{array}{ll}\text { 1.1 } & \text { Kebijakan pimpinan } \\
\text { 1.2 } & \text { Integritas kerja } \\
\text { 1.3 } & \text { Aturan kerja } \\
\text { 1.4 } & \text { Budaya kerja } \\
& \\
\text { 2.1 } & \text { Defragmentasi } \\
\text { 2.2 } & \text { Sasaran kerja } \\
\text { 2.3 } & \text { Kualitas kerja } \\
\text { 2.4 } & \text { Kuantitas kerja } \\
& \\
\text { 3.1 } & \text { Tersenyum } \\
\text { 3.2 } & \text { Ramah } \\
\text { 3.3 } & \text { Motif pelayanan } \\
\text { 3.4 } & \text { Sikap melayani }\end{array}$ & $\begin{array}{c}1 \\
2 \\
3 \\
4 \\
\\
5 \\
6 \\
7 \\
8 \\
\\
9 \\
10 \\
11 \\
12\end{array}$ \\
\hline $\begin{array}{c}\text { Zeithaml, } \\
\text { Parasuraman } \\
\text { dan Berry } \\
\text { (dalam } \\
\text { Ratminto dan } \\
\text { Atik, 2010: } \\
\text { 175) }\end{array}$ & $\begin{array}{c}\text { Y } \\
\text { Kualitas } \\
\text { Pelayanan }\end{array}$ & $\begin{array}{l}\text { 1. Tangibles } \\
\text { (ketampakan fisik) } \\
\text { 2. Reliability } \\
\text { (Keandalan) }\end{array}$ & $\begin{array}{ll}\text { 1.1 } & \text { Ruang tunggu } \\
\text { 1.2 } & \text { Toilet } \\
\text { 1.3 } & \text { Meja layanan } \\
\text { 1.4 } & \text { Tempat duduk } \\
\text { 1.5 } & \text { Formulir pendaftaran } \\
& \\
\text { 2.1 } & \text { Kemampuan } \\
\text { berkomunikasi } \\
\text { 2.2 } & \text { Kemampuan strategi } \\
\text { pelayanan } \\
\text { 2.3 } & \text { Kemampuan mengatasi } \\
\text { permasalahan } \\
\text { 2.4 } & \text { Inovasi pelayanan } \\
\text { 2.5 } & \text { Kreativitas pelayanan } \\
& \\
\text { 3.1 } & \text { Sikap tanggap } \\
& \text { memberikan pelayanan } \\
\text { 3.2 } & \text { Respon keluhan } \\
\text { 3.3 } & \text { Respon kesalahan data } \\
\text { 3.4 } & \text { Respon kritikan } \\
\text { 3.5 } & \text { Respon penerimaan } \\
& \text { usulan } \\
& \\
\text { 4.1 } & \text { Jaminan penyelesaian } \\
\text { 4.2 } & \text { Jaminan Data } \\
\text { 4.3 } & \text { Akurasi data } \\
\text { 4.4 } & \text { Ketepatan waktu } \\
\text { 4.5 } & \text { Solusi layanan } \\
& \\
\text { 5.1 } & \text { Perhatian memahami } \\
\text { kesulitan } \\
\text { 5.2 } & \text { Perhatian antrian } \\
& \text { layanan } \\
\text { 5.3 } & \text { Penerimaan keluhan } \\
\text { 5.4 } & \text { Keperdulian } \\
\text { 5.5 } & \text { Memahami layanan. }\end{array}$ & $\begin{array}{l}12 \\
13 \\
14 \\
15 \\
\\
16 \\
17 \\
18 \\
19 \\
20 \\
\\
21 \\
\\
22 \\
\\
23 \\
24 \\
25\end{array}$ \\
\hline
\end{tabular}

Teknik Sampling 1. Populasi Penelitian
Populasi dalam penelitian ini adalah penerima layanan rincian masing-masing 
populasi berjumlah 1.332 penerima pelayanan publik di Kantor Kelurahan Tengah dari Bulan Oktober, Nopember, Desember tahun 2014.

\section{Sampel Penelitian}

Sugiyono (2005: 56) memberikan pengertian bahwa "sampel adalah sebagian dari jumlah dan karakteristik yang dimiliki oleh populasi”. Dari pendapat tersebut dapat ditarik kesimpulan bahwa sampel adalah bagian dari populasi yang mempunyai ciri-ciri atau keadaan tertentu yang akan diteliti.

Untuk menghitung sampel menggunakan rumus Slovin sebagai berikut:

$$
\mathrm{n}=\frac{\mathrm{N}}{1+\mathrm{N}(\mathrm{e})^{2}}
$$

di mana :

$$
\begin{array}{lll}
\mathrm{n} & = & \text { ukuran sampel } \\
\mathrm{N} & = & \text { ukuran populasi } \\
\mathrm{e} & = & \begin{array}{l}
\text { persen kelongaran } \\
\text { ketidaktelitian karena } \\
\text { kesalahan pengambilan } \\
\text { sampel yang masih } \\
\text { dapat ditolerir atau } \\
\text { diinginkan, misalnya } \\
5 \% .
\end{array} \\
=\frac{1332}{1+1332(0,05)^{2}}=\frac{1332}{1+1332(0,0025)} \\
=\frac{1332}{1+3,33}=\frac{1332}{4.33}=
\end{array}
$$

dibulatkan 308 orang

Berdasarkan penghitungan sampel di dapat sampel rata-rata penerima pelayanan yang berlangsung di Kantor Kelurahan Tengah Kecamatan Cibinong Kabupaten Bogor berjumlah 308 orang.

\section{Teknik Analisis Data}

Teknik analisis data menggunakan Program SPSS 21.0 for Window, untuk melakukan pengujian sebagai berikut: (1) Uji Kualitas Data; (2) Teknik Analisis Data; (3) Uji Persyaratan Analisis; (4) Pengujian Kriteria Statistik; dan (5) Uji Hipotesis.

\section{Uji Hipotesis}

Rumusan pengujian hipotesis sebagai berikut:

1. $\mathrm{H}_{01}: \mathrm{b}_{01}=0$; tidak ada pengaruh positif dan signifikan Responsibilitas terhadap Kualitas Pelayanan

$\mathrm{H}_{\mathrm{a} 1}: \mathrm{b}_{\mathrm{a} 1}$ \# 0; terdapat pengaruh positif dan signifikan Responsibilitas terhadap Kualitas Pelayanan

Jika sig $<\alpha=0,05$, maka $\mathrm{H}_{01}$ ditolak dan $\mathrm{H}_{\mathrm{a} 1}$ diterima.

2. $\mathrm{H}_{02}: \mathrm{b}_{02}=0$; tidak ada pengaruh positif dan signifikan Sikap Kerja terhadap Kualitas Pelayanan

$\mathrm{H}_{\mathrm{a} 2}: \mathrm{b}_{\mathrm{a} 2}$ \# 0; terdapat pengaruh positif dan signifikan Sikap Kerja terhadap Kualitas Pelayanan

Jika sig $<\alpha=0,05$, maka $\mathrm{H}_{02}$ ditolak dan $\mathrm{H}_{\mathrm{a} 2}$ diterima.

3. $\mathrm{H}_{03}: \mathrm{b}_{1}=\mathrm{b}_{2}=0$; tidak ada pengaruh positif dan signifikan Responsibilitas dan Sikap Kerja secara bersama-sama terhadap Kualitas Pelayanan

$\mathrm{H}_{\mathrm{a} 3}$ : salah satu atau kedua $\mathrm{b} \neq 0$; terdapat pengaruh positif dan signifikan Responsibiulitas dan Sikap Kerja secara bersama-sama terhadap Kualitas Pelayanan Jika sig $<\alpha=0,05$, maka $\mathrm{H}_{03}$ ditolak dan $\mathrm{H}_{\mathrm{a} 3}$ diterima (Tabel Anova).

\section{HASIL PENELITIAN DAN PEMBAHASAN \\ Hasil Penelitian \\ 1. Deskripsi Data Penelitian}

Karakteristik responden menurut jenis kelamin dalam penelitian ini dapat dilihat pada tabel berikut: 
A.H. Rahadian dan Bambang Rusantono, Pengaruh Responsibilitas dan Sikap .....

Tabel 2 Karakteristik Responden Penelitian Menurut Jenis Kelamin

\begin{tabular}{|c|c|c|c|c|}
\hline No & Pertanyaan & Alternatif Jawaban & Jumlah & $(\%)$ \\
\hline 1 & \multirow[t]{2}{*}{ Jenis Kelamin } & Laki - laki & 203 & 65,9 \\
\hline \multirow[t]{2}{*}{2} & & Perempuan & 105 & 34,1 \\
\hline & & Total & 308 & 100 \\
\hline
\end{tabular}

Sumber: Karakteristik Responden Penelitian

Tabel di atas menunjukkan 203 responden atau $65,9 \%$ menurut jenis kelamin adalah laki-laki. Kondisi responden penelitian ini menunjukkan bahwa laki-laki lebih dominan mempengaruhi penerima layanan untuk menjawab kondisi dan situasi yang dirasakan oleh penerima layanan di Kelurahan Tengah Kecamatan Cibinong Kabupaten Bogor.

Karakteristik responden menurut tingkat pendidikan terakhir dalam penelitian ini dapat dilihat pada tabel berikut:

Tabel 3 Karakteristik Responden Penelitian Menurut Tingkat Pendidikan Formal

\begin{tabular}{|c|c|c|c|c|}
\hline No & Pertanyaan & Alternatif Jawaban & Jumlah & $(\%)$ \\
\hline 1 & \multirow{5}{*}{$\begin{array}{l}\text { Pendidikan } \\
\text { Formal }\end{array}$} & SLTP/Sederajat & 8 & 2,6 \\
\hline 2 & & SLTA/Sederajat & 150 & 48,7 \\
\hline 3 & & Akademi/ D3 & 50 & 16,23 \\
\hline 4 & & Sarjana/Strata 1 & 95 & 30,85 \\
\hline 5 & & Magister/Strata 2 & 5 & 1,62 \\
\hline & & Total & 308 & 100 \\
\hline
\end{tabular}

Sumber: Karakteristik Responden Penelitian

Tabel di atas dapat menunjukkan 95 responden atau 30,85\% dari jumlah responden penelitian berlatar belakang pendidikan tinggi Sajana/S1 dan sebanyak 5 responden atau $1,62 \%$ penelitian berlatar belakang Magister/S2, 150 responden atau $48,7 \%$ berlatar belakang pendidikan SLTA/Sederajat, dan 8 responden atau 2,6\% berlatar belakang pendidikan SLTP/Sederajat. Kondisi karakteristik responden penelitian ini menunjukkan bahwa tingkat pendidikan formal karakteristik para responden sebagai penerima layanan di Kelurahan Tengah
Kecamatan Cibinong Kabupaten Bogor dapat dianggap cukup representatif untuk mengungkapkan masalah yang dijadikan objek penelitian secara objektif. Dengan demikian pertanyaaan yang diajukan untuk menggali masalah yang dijadikan objek penelitian masuk kepada pihak yang layak dianggap dapat merepresentasikan objek penelitian secara kritis dan objektif.

Karakteristik responden menurut kelompok usia dalam penelitian ini dapat dilihat pada tabel berikut:

Tabel 4 Karakteristik Responden Menurut Kelompok Usia

\begin{tabular}{|c|c|c|c|c|}
\hline No & Pertanyaan & Alternatif Jawab & Jumlah & $(\%)$ \\
\hline 1 & \multirow{3}{*}{$\begin{array}{c}\text { Kelompok } \\
\text { Usia }\end{array}$} & Di bawah $\leq 30$ tahun & 58 & 18,83 \\
\hline 2 & & 31 sampai dengan 40 tahun & 150 & 48,7 \\
\hline 3 & & $\geq 40$ tahun & 100 & 32,47 \\
\hline & & & 308 & 100 \\
\hline
\end{tabular}

Sumber: Karakteristik Responden Penelitian

Dari data di atas terungkap bahwa sebagian besar responden penelitian 150 atau
48,7\% dari jumlah sampel berusia 31 sampai dengan 40 tahun. Kelompok usia ini dapat 
dianggap sebagai para pihak yang telah matang dalam menerima dan merasakan kualitas pelayanan di Kelurahan Tengah Kecamatan Cibinong Kabupaten Bogor sedangkan usia dibawah 30 tahun ada 58 responden atau $18,83 \%$ sedangkan yang diatas 40 tahun ada 100 responden $32,47 \%$.

\section{Uji Kualitas Data}

Hasil penghitungan koefisien validitas seluruh item Instrumen penelitian Responsibilitas, Sikap Kerja, dan Kualitas Pelayanan pada kolom Corrected Item-Total Correlation lebih besar dari $\mathrm{r}$ Tabel sebesar 0,113 . Interpretasinya valid. Hasil valid tersebut bermakna bahwa indikator-indikator penelitian dapat dipergunakan sebagai alat pengumpul data untuk mengukur Responsibilitas, Sikap Kerja, dan Kualitas Pelayanan. reliabilitas:

Selanjutnya, hasil pengujian

Responsibilitas, Koefisien Reliabilitas atau 0,707 lebih besar dari angka penguji 0,60 , maka hasil pengujian reliabilitas pada variabel Responsibilitas dapat dinyatakan reliabel atau dapat diandalkan.

Sikap Kerja, Koefisien Reliabilitas atau 0,668 lebih besar dari angka penguji 0,60, maka hasil pengujian reliabilitas pada variabel Sikap Kerja dapat dinyatakan reliabel atau dapat diandalkan.

Kualitas Pelayanan, Koefisien Reliabilitas atau 0,780 lebih besar dari angka penguji 0,60, maka hasil pengujian reliabilitas pada variabel Kualitas Pelayanan di Kelurahan Tengah Kecamatan Cibinong Kabupaten Bogor dapat dinyatakan reliabel atau dapat diandalkan.

\section{Teknik Analisis Data}

Penyusunan distribusi frekuensi menurut aturan Sturges, didapat hasil:

Instrumen Responsibilitas, skor ratarata terletak pada nomor kelas ke tujuh dengan interval kelas, dengan skor antara 5860 , skor rata-rata sebesar 58,45 sebanyak 47 responden atau $15,26 \%$, skor di bawah ratarata mulai dari nomor kelas kesatu sampai keenam sebanyak 128 responden atau 41,56\% dan skor di atas rata-rata dari nomor kelas kedelapan sampai kesembilan sebanyak 133 responden atau $43,18 \%$.

Instrumen Sikap Kerja, skor rata-rata terletak pada nomor kelas ke enam dengan interval kelas, dengan skor antara 47-49, skor rata-rata sebesar 47,16 sebanyak 70 responden atau $22,73 \%$, skor di bawah ratarata mulai dari nomor kelas kesatu sampai kelima sebanyak 131 responden atau $42,53 \%$ dan skor di atas rata-rata dari nomor kelas ketujuh sampai kesembilan sebanyak 107 responden atau $34,74 \%$.

Instrumen Kualitas Pelayanan, skor rata-rata terletak pada nomor kelas ke enam dengan interval kelas, dengan skor antara 95 - 99, skor rata-rata sebesar 97,77 sebanyak 68 responden atau $22,08 \%$, skor di bawah ratarata mulai dari nomor kelas kesatu sampai kelima sebanyak 97 responden atau 31,49\% dan skor di atas rata-rata dari nomor kelas ketujuh sampai kesembilan sebanyak 141 responden atau $46,43 \%$.

\section{Uji Persyaratan Analisis \\ a. Uji Normalitas}

Uji normalitas bertujuan untuk menguji apakah dalam model regresi, variabel pengganggu atau residual memiliki distribusi normal.

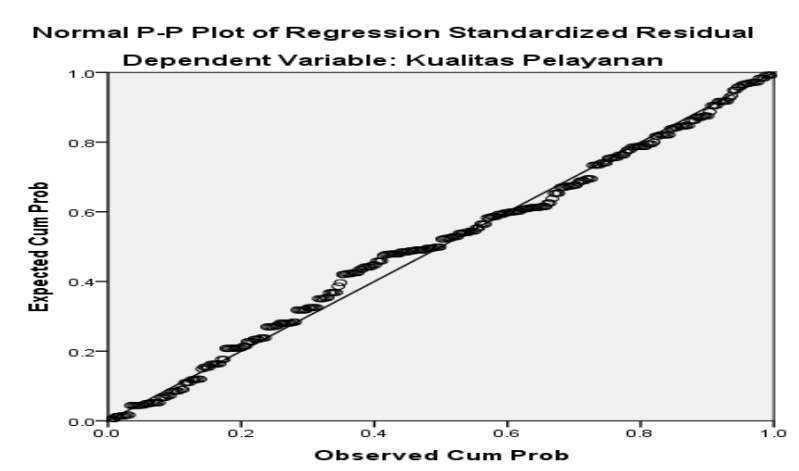




\section{Grafik 1 Grafik Histogram Normalitas Data}

Berdasarkan grafik normal plot Kualitas Pelayanan di Kelurahan Tengah tersebut di atas terlihat titik-titik menyebar disekitar garis diagonal serta penyebarannya mengikuti arah garis diagonal. Grafik ini menujukkan bahwa model regresi memenuhi asumsi normalitas. Dengan demikian dapat disimpulkan bahwa model regresi pengaruh Responsibilitas dan Sikap Kerja terhadap

Kecamatan Cibinong Kabupaten Bogor menunjukkan pola distribusi normal

\section{b. Uji Linieritas}

Uji linieritas model regresi antara variabel bebas $X_{1}$ dan $X_{2}$ dengan variabel terikat $\mathrm{Y}$ dengan melihat grafik scatterplot.

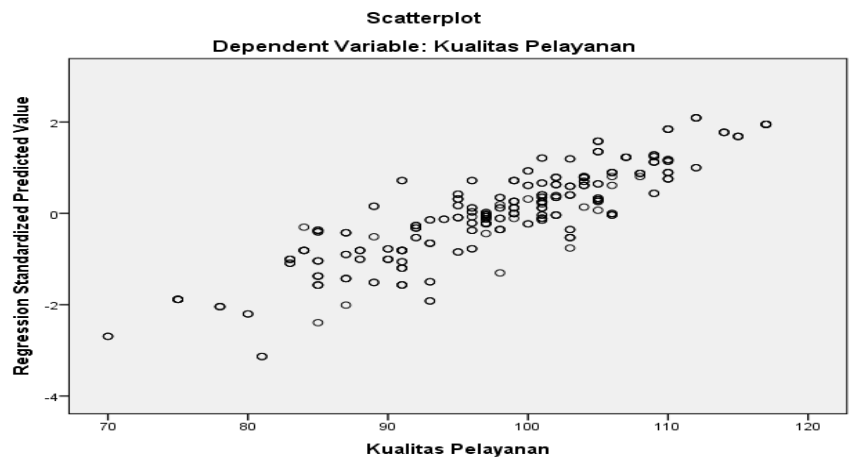

Grafik 2 Hasil Uji Linieritas

Berdasarkan grafik tersebut di atas, terlihat sebaran data membentuk arah garis lurus dari kiri bawah ke kanan atas. Oleh karena itu asumsi model regresi harus linier terpenuhi.

\section{c. Uji Autokorelasi}

Hasil perhitungan Durbin-Watson statistik dapat diketahui pada tabel berikut ini:

Tabel 5

Hasil Uji Autokorelasi

Model Summary ${ }^{\text {b }}$

\begin{tabular}{|l|r|r|r|}
\hline Model & \multicolumn{1}{|c|}{$\mathrm{R}$} & R Square & \multicolumn{1}{c|}{ Durbin-Watson } \\
\hline 1 & $.875^{\mathrm{a}}$ & .766 & 1.593 \\
\hline
\end{tabular}

a. Predictors: (Constant), Sikap Kerja, Responsibilitas

b. Dependent Variable: Kualitas Pelayanan

Sumber: Diolah dari hasil penelitian

Hasil pengujian diketahui nilai Durbin-Watson (DW) sebesar 1,593. Oleh karena nilai DW berada di atas 1 dan lebih kecil dari 3 atau $1<1,593<3$, maka tidak ada autokorelasi. Dengan demikian, dapat disimpulkan bahwa dalam model regresi ganda antara variabel bebas Responsibilitas $\left(\mathrm{X}_{1}\right)$, dan Sikap Kerja $\left(\mathrm{X}_{2}\right)$, terhadap Kualitas
Pelayanan di Kelurahan Tengah Kecamatan Cibinong Kabupaten Bogor (Y) tidak terjadi autokorelasi.

\section{d. Uji Multikolinieritas}

Hasil uji multikolinieritas adalah sebagai berikut:

Tabel 6

Hasil Uji Multikolinieritas

Coefficients $^{\mathrm{a}}$

\begin{tabular}{|l|r|r|}
\hline \multirow{2}{*}{ Model } & \multicolumn{2}{|c|}{ Collinearity Statistics } \\
\cline { 2 - 3 } & Tolerance & \multicolumn{1}{c|}{ VIF } \\
\hline Responsibilitas &, 411 & 2,434 \\
Sikap Kerja &, 411 & 2,434 \\
\hline
\end{tabular}

a. Dependent Variable: Kualitas Pelayanan

Sumber: Diolah dari hasil penelitian 
Hasil pengujian diketahui nilai VIF berada di bawah angka 10 atau 2,434 untuk semua variabel bebas. Demikian pula, nilai tolerance lebih besar dari 0,10 untuk semua variabel bebas atau 0,411. Dengan demikian, dapat disimpulkan bahwa dalam regresi antara variabel bebas Responsibilitas $\left(\mathrm{X}_{1}\right)$, dan Sikap Kerja $\left(\mathrm{X}_{2}\right)$ terhadap Kualitas Pelayanan di Kelurahan Tengah Kecamatan Cibinong Kabupaten Bogor (Y) tidak terjadi multikolinieritas antar variabel bebas.

\section{e. Uji Heteroskedastisitas}

Dasar analisisnya, jika ada pola tertentu seperti titik-titik yang ada membentuk pola tertentu yang teratur (bergelombang, menyebar kemudian menyempit), maka mengindikasikan telah terjadi heteroskedastisitas. Sebaliknya jika tidak ada pola yang jelas serta titik-titik menyebar di atas dan di bawah angka 0 pada sumbu Y, maka tidak terjadi heteroskedastisitas.

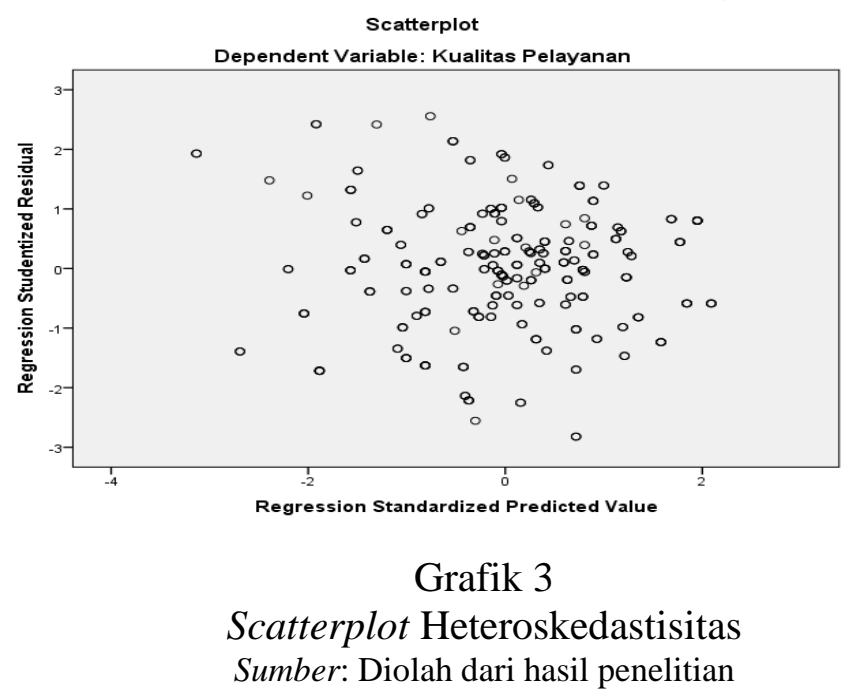

Berdasarkan grafik scatterplot terlihat bahwa titik-titik menyebar secara acak serta tersebar baik di atas maupun di bawah angka 0 pada sumbu Y. Dengan demikian dapat disimpulkan tidak terjadi heteroskedastisitas pada model regresi. Dengan demikian asumsi yang menyatakan bahwa dalam model regresi tidak terjadi heteroskedastisitas dapat dipenuhi.

\section{Pengujian Kriteria Statistik}

a. Pengaruh Responsibilitas terhadap Kualitas Pelayanan di Kelurahan Tengah Kecamatan Cibinong Kabupaten Bogor

Berdasarkan pengolahan statistik dengan program SPSS 21 for windows diperoleh hasil :

Tabel 7

Hasil pengukuran koefisien korelasi dan koefisien determinasi

Responsibilitas terhadap Kualitas Pelayanan di Kelurahan Tengah Kecamatan Cibinong Kabupaten

Bogor

Model Summary

\begin{tabular}{|l|r|r|r|r|}
\hline Model & $\mathrm{R}$ & R Square & Adjusted R Square & \multicolumn{2}{|c|}{$\begin{array}{c}\text { Std. Error of the } \\
\text { Estimate }\end{array}$} \\
\hline 1 & $.824^{\mathrm{a}}$ & .679 & .678 & 5.213 \\
\hline
\end{tabular}

a. Predictors: (Constant), Responsibilitas

Sumber: Diolah dari hasil penelitian 
Hasil pengukuran koefisien korelasi menunjukkan bahwa hubungan yang terjalin di antara variabel Responsibilitas dengan variabel Kualitas Pelayanan di Kelurahan Tengah Kecamatan Cibinong Kabupaten Bogor mencapai 0,824 yang diinterpretasikan tinggi karena terletak antara 0,800 sampai dengan 1,000. (Tabel intrepretasi nilai r)

Selanjutnya, Koefisien korelasi ini terbilang positif dan sangat signifikan. Artinya, di antara variabel Responsibilitas dengan variabel Kualitas Pelayanan di Kelurahan Tengah Kecamatan Cibinong Kabupaten Bogor terjalin suatu mekanisme hubungan kausalitas.

Hasil penghitungan statistik Koefisien Determinasi $\left(\mathrm{r}^{2}\right)$ atau $R$ square diketahui bahwa Koefisien Determinasi di antara variabel Responsibilitas dengan variabel Kualitas Pelayanan di Kelurahan Tengah Kecamatan Cibinong Kabupaten Bogor mencapai 0,679. Artinya, 67,9\% keragaman Kualitas Pelayanan di Kelurahan Tengah Kecamatan Cibinong Kabupaten Bogor dapat dijelaskan dari variabel Responsibilitas, dan atau besaran kontribusi variabel Responsibilitas terhadap variabel Kualitas Pelayanan di Kelurahan Tengah Kecamatan Cibinong Kabupaten Bogor mencapai 67,9\%. Sisanya sebesar 32,1\% merupakan kontribusi faktor-faktor lain terhadap variabel Kualitas Pelayanan di Kelurahan Tengah Kecamatan Cibinong Kabupaten Bogor, namun tidak diteliti.

Tabel 8

Hasil Pengukuran Koefisien Regresi Sederhana Responsibilitas terhadap Kualitas Pelayanan di Kelurahan Tengah Kecamatan Cibinong Kabupaten Bogor

Coefficients $^{\mathrm{a}}$

\begin{tabular}{|rl|r|r|r|r|r|}
\hline Model & \multicolumn{2}{|c|}{$\begin{array}{c}\text { Unstandardized } \\
\text { Coefficients }\end{array}$} & $\begin{array}{l}\text { Standardized } \\
\text { Coefficients }\end{array}$ & \multicolumn{1}{c|}{ Sig. } \\
\cline { 3 - 5 } & & \multicolumn{1}{|c|}{ B } & Std. Error & \multicolumn{1}{c|}{ Beta } & & \\
\hline \multirow{2}{*}{1} & (Constant) & 25.653 & 2.848 & & 9.008 & .000 \\
& Responsibilitas & 1.234 & .048 & .824 & 25.460 & .000 \\
\hline
\end{tabular}

a. Dependent Variable: Kualitas Pelayanan Sumber: Diolah dari hasil penelitian

Berdasarkan tabel diatas diketahui bahwa persamaan regresi sederhana $\hat{\mathrm{Y}}=$ $25,653+1,234 \mathrm{X}_{1}$. Hasil pengukuran persamaan regresi sederhana menunjukkan bahwa pengaruh variabel Responsibilitas terhadap variabel Kualitas Pelayanan di Kelurahan Tengah Kecamatan Cibinong Kabupaten Bogor mencapai (b) $=1,234$. Koefisien regresi ini terbilang positif, dan signifikan, serta bermakna: Apabila Responsibilitasditingkatkan atau meningkat, maka peningkatan Responsibilitastersebut akan diikuti dengan peningkatan Kualitas Pelayanan di Kelurahan Tengah Kecamatan Cibinong Kabupaten Bogor.

\section{b. Pengaruh Sikap Kerja Terhadap Kualitas Pelayanan di Kelurahan Tengah Kecamatan Cibinong Kabupaten Bogor \\ Berdasarkan pengolahan statistik} dengan program SPSS 21 for windows diperoleh hasil sebagai berikut:

Tabel 9

Hasil pengukuran koefisien korelasi dan koefisien determinasi

Sikap Kerja terhadap Kualitas Pelayanan di Kelurahan Tengah Kecamatan Cibinong Kabupaten

Bogor

Model Summary

\begin{tabular}{|l|r|r|r|r|}
\hline Model & \multicolumn{1}{|c|}{$\mathrm{R}$} & R Square & Adjusted R Square & $\begin{array}{c}\text { Std. Error of the } \\
\text { Estimate }\end{array}$ \\
\hline 1 & $.822^{\mathrm{a}}$ & .675 & .674 & 5.249 \\
\hline
\end{tabular}

a. Predictors: (Constant), Sikap Kerja

Sumber : Diolah dari hasil penelitian 
Hasil pengukuran koefisien korelasi menunjukkan bahwa hubungan yang terjalin di antara variabel Sikap Kerja dengan variabel Kualitas Pelayanan di Kelurahan Tengah Kecamatan Cibinong Kabupaten Bogor mencapai 0,822 yang diinterpretasikan tinggi karena terletak antara 0,800 sampai dengan 1,000. (Tabel intrepretasi nilai r)

Selanjutnya, Koefisien korelasi ini terbilang positif, signifikan dan kuat. Artinya, di antara variabel Sikap Kerja dengan variabel Kualitas Pelayanan di Kelurahan Tengah Kecamatan Cibinong Kabupaten Bogor terjalin suatu mekanisme hubungan kausalitas.

Berdasarkan hasil penghitungan statistik Koefisien Determinasi $\left(\mathrm{r}^{2}\right)$ atau $R$ square diketahui bahwa Koefisien Determinasi di antara variabel Sikap Kerja dengan variabel Kualitas Pelayanan di Kelurahan Tengah Kecamatan Cibinong Kabupaten Bogor mencapai 0,675. Artinya, $67,5 \%$ keragaman Kualitas Pelayanan di Kelurahan Tengah Kecamatan Cibinong Kabupaten Bogor dapat dijelaskan dari variabel Sikap Kerja, dan atau besaran kontribusi variabel Sikap Kerja terhadap variabel Kualitas Pelayanan di Kelurahan Tengah Kecamatan Cibinong Kabupaten Bogor mencapai $67,5 \%$. Sisanya $32,5 \%$ merupakan kontribusi faktor-faktor lain terhadap variabel Kualitas Pelayanan di Kelurahan Tengah Kecamatan Cibinong Kabupaten Bogor, namun tidak diteliti.

Tabel 10

Hasil Pengukuran Koefisien Regresi Sederhana Sikap Kerja terhadap Kualitas Pelayanan di Kelurahan Tengah

Kecamatan Cibinong Kabupaten Bogor

Coefficients $^{\mathrm{a}}$

\begin{tabular}{|rl|r|r|r|r|r|}
\hline \multicolumn{2}{|l|}{ Model } & \multicolumn{2}{|c|}{$\begin{array}{l}\text { Unstandardized } \\
\text { Coefficients }\end{array}$} & \multicolumn{1}{c|}{$\begin{array}{c}\text { Standardized } \\
\text { Coefficients }\end{array}$} & \multicolumn{1}{c|}{ Sig. } & \\
\cline { 3 - 5 } & \multicolumn{1}{|c|}{ B } & Std. Error & \multicolumn{1}{c|}{ Beta } & & \\
\hline \multirow{2}{*}{1} & (Constant) & 26.038 & 2.862 & & 9.099 & .000 \\
& Sikap Kerja & 1.521 & .060 & .822 & 25.202 & .000 \\
\hline
\end{tabular}

Sumber: Diolah dari hasil penelitian

Berdasarkan tabel diatas diketahui bahwa persamaan regresi sederhana $\hat{\mathrm{Y}}=$ $26,038+1,521 \mathrm{X}_{2}$. Hasil pengukuran persamaan regresi sederhana ini menunjukkan bahwa pengaruh variabel Sikap Kerja terhadap variabel Kualitas Pelayanan di Kelurahan Tengah Kecamatan Cibinong Kabupaten Bogor mencapai (b) $=1,521$. Koefisien regresi ini terbilang positif, kuat dan signifikan, serta bermakna : Apabila Sikap Kerja ditingkatkan atau meningkat, maka peningkatan tersebut akan diikuti dengan peningkatan Kualitas Pelayanan di Kelurahan Tengah Kecamatan Cibinong Kabupaten Bogor.

\section{c. Pengaruh Responsibilitas dan Sikap Kerja secara bersama-sama terhadap Kualitas Pelayanan di Kelurahan Tengah Kecamatan Cibinong Kabupaten Bogor}

Berdasarkan pengolahan statistik dengan program SPSS 21 for windows diperoleh hasil sebagai berikut:

Tabel 11

Hasil Pengukuran Koefisien Korelasi Ganda dan Koefisien Determinasi Ganda Responsibilitasdan Sikap Kerja Secara Bersamasama Terhadap Kualitas Pelayanan di Kelurahan Tengah

Kecamatan Cibinong Kabupaten Bogor Model Summary ${ }^{\mathbf{b}}$ 


\begin{tabular}{|l|r|r|r|r|}
\hline Model & R & R Square & \multicolumn{1}{|c|}{$\begin{array}{c}\text { Adjusted R } \\
\text { Square }\end{array}$} & $\begin{array}{c}\text { Std. Error of the } \\
\text { Estimate }\end{array}$ \\
\hline 1 & $.875^{\mathrm{a}}$ & .766 & .765 & 4.458 \\
\hline
\end{tabular}

a. Predictors: (Constant), Sikap Kerja, Responsibilitas

b. Dependent Variable: Kualitas Pelayanan

Sumber: Diolah dari hasil penelitian

Hasil pengukuran koefisien korelasi ganda menunjukkan bahwa hubungan yang terjalin di antara variabel Responsibilitas dan Sikap Kerja secara bersama-sama dengan variabel Kualitas Pelayanan di Kelurahan Tengah Kecamatan Cibinong Kabupaten Bogor mencapai 0,875 yang diinterpretasikan Tinggi karena terletak antara 0,800 sampai dengan 1,00. (Tabel intrepretasi nilai $r$ )

Selanjutnya, Koefisien korelasi ini terbilang positif, sangat kuat dan signifikan. Artinya, di antara variabel Responsibilitasdan variabel Sikap Kerja secara bersama-sama dengan variabel Kualitas Pelayanan di Kelurahan Tengah Kecamatan Cibinong Kabupaten Bogor terjalin suatu mekanisme hubungan kausalitas.

Berdasarkan hasil penghitungan statistik Koefisien Determinasi $\left(\mathrm{r}^{2}\right)$ atau $R$ square diketahui bahwa Koefisien
Determinasi di antara variabel Responsibilitasdan variabel Sikap Kerja secara bersama-sama dengan variabel Kualitas Pelayanan di Kelurahan Tengah Kecamatan Cibinong Kabupaten Bogor mencapai 0,766. Artinya, 76,6\% keragaman Kualitas Pelayanan di Kelurahan Tengah Kecamatan Cibinong Kabupaten Bogor dapat dijelaskan dari variabel Responsibilitas dan variabel Sikap Kerja, dan atau besaran kontribusi variabel Responsibilitas dan variabel Sikap Kerja secara bersama-sama terhadap variabel Kualitas Pelayanan di Kelurahan Tengah Kecamatan Cibinong Kabupaten Bogor mencapai 76,6\%. Sisanya sebesar 23,4\% merupakan kontribusi faktorfaktor lain terhadap variabel Kualitas Pelayanan di Kelurahan Tengah Kecamatan Cibinong Kabupaten Bogor namun tidak diteliti.

Tabel 12

Hasil Pengukuran Koefisien Regresi Ganda Kompetensi Pegawai dan Sikap Kerja secara bersama-sama terhadap Kualitas Pelayanan di Kelurahan Tengah Kecamatan Cibinong Kabupaten Bogor

Coefficients $^{\mathbf{a}}$

\begin{tabular}{|rl|r|r|r|r|r|}
\hline Model & \multicolumn{2}{|c|}{$\begin{array}{c}\text { Unstandardized } \\
\text { Coefficients }\end{array}$} & $\begin{array}{c}\text { Standardized } \\
\text { Coefficients }\end{array}$ & \multirow{2}{*}{ Sig. } \\
\cline { 3 - 5 } & & \multicolumn{1}{|c|}{$\mathrm{B}$} & \multicolumn{1}{c|}{ Std. Error } & \multicolumn{1}{c|}{ Beta } & & \\
\hline \multirow{2}{*}{1} & (Constant) & 16.385 & 2.587 & & 6.334 & .000 \\
& Responsibilitas & .706 & .065 & .471 & 10.912 & .000 \\
& Sikap Kerja & .851 & .080 & .460 & 10.643 & .000 \\
\hline
\end{tabular}

a. Dependent Variable: Kualitas Pelayanan

Sumber: Diolah dari hasil penelitian

Berdasarkan tabel di atas diketahui bahwa hasil persamaan regresi ganda $\hat{\mathrm{Y}}=$ $16,385+0,706 X_{1}+0,851 X_{2}$ Hasil pengukuran persamaan regresi ganda menunjukkan bahwa pengaruh variabel Responsibilitas terhadap variabel Kualitas Pelayanan di Kelurahan Tengah Kecamatan Cibinong Kabupaten Bogor mencapai $\left(b_{1}\right)=$ 0,706 dan pengaruh variabel Sikap Kerja terhadap variabel Kualitas Pelayanan di
Kelurahan Tengah Kecamatan Cibinong Kabupaten Bogor mencapai $\left(b_{2}\right)=0,851$.

Hasil penghitungan persamaan regresi ganda itu diketahui bahwa kontribusi pengaruh variabel Sikap Kerja lebih besar dari kontribusi pengaruh variabel Responsibilitas terhadap Kualitas Pelayanan di Kelurahan Tengah Kecamatan Cibinong Kabupaten Bogor. 


\section{Uji Hipotesis}

\section{Hasil Uji Hipotesis Pertama}

Nilai Sig sebesar 0,000. Karena sig < $\alpha=0,05$, maka $\mathrm{H}_{0}$ ditolak dan $\mathrm{H}_{\mathrm{a}}$ diterima. Dengan demikian teruji bahwa terdapat pengaruh positif dan signifikan Responsibilitas terhadap Kualitas Pelayanan di Kelurahan Tengah Kecamatan Cibinong Kabupaten Bogor.

\section{Hasil Uji Hipotesis Kedua}

Nilai Sig sebesar 0,000. Karena sig < $\alpha=0,05$, maka $\mathrm{H}_{0}$ ditolak dan $\mathrm{H}_{\mathrm{a}}$ diterima. Dengan demikian teruji bahwa terdapat pengaruh positif dan signifikan Sikap Kerja terhadap Kualitas Pelayanan di Kelurahan Tengah Kecamatan Cibinong Kabupaten Bogor.

\section{Hasil Uji Hipotesis Ketiga}

Nilai Sig sebesar 0,000. Karena sig < $\alpha=0,05$, maka $\mathrm{H}_{0}$ ditolak dan $\mathrm{H}_{\mathrm{a}}$ diterima. Dengan demikian teruji bahwa terdapat pengaruh positif dan signifikan Responsibilitas dan Sikap Kerja secara bersama-sama terhadap Kualitas Pelayanan di Kelurahan Tengah Kecamatan Cibinong Kabupaten Bogor.

\section{Pembahasan}

\section{Hasil Pengaruh Responsibilitas terhadap Kualitas Pelayanan di Kelurahan Tengah Kecamatan Cibinong Kabupaten Bogor}

Hasil uji hipotesis dan perhitungan data statistik diperoleh hasil bahwa terdapat hubungan antara Responsibilitas dengan Kualitas Pelayanan di Kelurahan Tengah Kecamatan Cibinong Kabupaten Bogor sebesar 0,824 dan sedangkan besarnya Pengaruh Responsibilitas terhadap Kualitas Pelayanan di Kelurahan Tengah Kecamatan Cibinong Kabupaten Bogor sebesar 67,9\% sisanya sebesar $32,1 \%$ merupakan kontribusi faktor-faktor lain terhadap variabel, namun tidak diteliti. Secara kausalitas Pengaruh Responsibilitas terhadap Kualitas Pelayanan di Kelurahan Tengah Kecamatan Cibinong Kabupaten Bogor sebesar 1,234 yang ditunjukkan oleh persamaan regresi sederhana $\hat{\mathrm{Y}}=25,653+1,234 \mathrm{X}_{1}$.

Hasil analisis dapat diinterprestasikan bahwa Pengaruh Responsibilitas merupakan kemampuan pegawai Kelurahan Tengah dalam merespon keinginan masyarakat yang dilandasi keterampilan dan pengetahuan serta didukung oleh sikap kerja yang dituntut oleh bawahan yang meliputi: Instruktif, Konsultasi, Partisipasi dan Delegasi. Seperti yang dikemukakan oleh Sutrisno (2014: 17) menjelaskan tentang gaya kepemimpinan. Hal ini sejalan dengan responsibilitas yang berlangsung di Kelurahan Tengah Kecamatan Cibinong Kabupaten Bogor untuk Kualitas Pelayanan di Kelurahan Tengah Kecamatan Cibinong Kabupaten Bogor.

Responsibilitas yang berlangsung di Kelurahan Tengah Kecamatan Cibinong Kabupaten Bogor terungkap dari pengetahuan dan keterampilan dalam merespon masukan dari masyarakat dalam menyusun evaluasi kerja sehingga jika ada target dan realisasi yang belum tercapai serta kemampuan dalam menjaga hubungan antara pegawai dengan masyarakat sebagai pemberi penerima layanan.

Berdasarkan temuan hasil penelitian menyatakan bahwa terdapat pengaruh positif dan siginifikan Responsibilitas terhadap Kualitas Pelayanan di Kelurahan Tengah Kecamatan Cibinong Kabupaten Bogor. Hasil penelitian didukung pula oleh Pribadi et al. (2014) menyebutkan terdapat pengaruh positif dan signifikan Responsibilitas terhadap dengan Kualitas Pelayanan. Selain itu, ditunjukan adanya kesamaan pada penggunaan metode analisis yaitu kuantitatif namun tidak menunjukkan adanya hubungan kausalitas an tidak diperjelas dengan analisis deskriptif.

\section{Hasil Pengaruh Sikap Kerja terhadap Kualitas Pelayanan di Kelurahan Tengah Kecamatan Cibinong Kabupaten Bogor \\ Hasil uji hipotesis dan perhitungan} data statistik diperoleh hasil bahwa terdapat hubungan antara Sikap Kerja dengan Kualitas Pelayanan di Kelurahan Tengah Kecamatan Cibinong Kabupaten Bogor sebesar 0,822 dan sedangkan besarnya pengaruh Sikap Kerja terhadap Kualitas Pelayanan di Kelurahan Tengah Kecamatan Cibinong Kabupaten Bogor sebesar $67,5 \%$ sisanya sebesar $32,5 \%$ merupakan kontribusi faktor-faktor lain 
terhadap variabel, namun tidak diteliti. Secara kausalitas pengaruh Sikap Kerja terhadap Kualitas Pelayanan di Kelurahan Tengah Kecamatan Cibinong Kabupaten Bogor sebesar 1,521 yang ditunjukkan oleh persamaan regresi sederhana $\hat{\mathrm{Y}}=26,038+$ $1,521 X_{2}$

Hasil analisis dapat diinterprestasikan bahwa Sikap Kerja merupakan kemampuan melakukan suatu tugas yang dilandasi atas keterampilan dan pengetahuan serta didukung oleh sikap kerja yang dituntut oleh pekerjaan yang meliputi: konigtif, afektif dan behavioral. Seperti yang dikemukakan oleh Robbin (2006: 93) menjelaskan pentingnya Sikap Kerja. Hal ini sejalan dengan sikap kerja yang berlangsung di Kelurahan Tengah Kecamatan Cibinong Kabupaten Bogor untuk meningkatkan Hasil Pengaruh Sikap Kerja terhadap Kualitas Pelayanan di Kelurahan Tengah Kecamatan Cibinong Kabupaten Bogor.

Sikap kerja yang berlangsung di Kelurahan Tengah Kecamatan Cibinong Kabupaten Bogor terungkap dari pengetahuan dan keterampilan dalam memberikan sikap kerjanya dalam pelayanan dan menyusun evaluasi kerja sehingga adanya target dan realisasi yang belum tercapai serta kemampuan dalam menjaga sikap dalam memberikan pelayanan kepada masyarakat.

Berdasarkan temuan hasil penelitian menyatakan bahwa terdapat pengaruh positif dan siginifikan Sikap Kerja terhadap Kualitas Pelayanan di Kelurahan Tengah Kecamatan Cibinong Kabupaten Bogor. Hasil penelitian didukung pula oleh Hidayati (Tesis, 2011) menyebutkan terdapat pengaruh positif dan signifikan sikap kerja terhadap kualitas pelayanan. Selain itu, ditunjukan adanya kesamaan pada penggunaan metode analisis yaitu kuantitatif, namun adanya perbedaan analisis resgresi yang tidak memperjelas antar variabel dan tidak menunjukkan adanya uji asumsi klasik dan deskriptif.
3. Hasil Pengaruh Responsibilitas dan Sikap Kerja secara bersama-sama terhadap Kualitas Pelayanan di Kelurahan Tengah Kecamatan Cibinong Kabupaten Bogor

Hasil uji hipotesis dan perhitungan data statistik diperoleh hasil bahwa terdapat pengaruh positif dan signifikan Pengaruh Responsibilitasdan Sikap Kerja secara bersama-sama terhadap Kualitas Pelayanan di Kelurahan Tengah Kecamatan Cibinong Kabupaten Bogor. Untuk besarnya hubungan Responsibilitasdan Sikap Kerja secara bersama-sama dengan Kualitas Pelayanan di Kelurahan Tengah Kecamatan Cibinong Kabupaten Bogor sebesar 0,875 yang menunjukkan hubungan tersebut sangat kuat. Sedangkan besarnya pengaruh Responsibilitasdan Sikap Kerja secara bersama-sama terhadap Kualitas Pelayanan di Kelurahan Tengah Kecamatan Cibinong Kabupaten Bogor sebesar 76,6\% sisanya sebesar 23,4\% merupakan kontribusi faktorfaktor lain terhadap variabel, namun tidak diteliti.

Secara kausalitas Pengaruh Responsibilitas dan Sikap Kerja secara bersama-sama terhadap Kualitas Pelayanan di Kelurahan Tengah Kecamatan Cibinong Kabupaten Bogor sebesar 0,706 untuk Responsibilitas dan sebesar 0,851 untuk Sikap Kerja. Garis persamaan regresi berganda ditunjukan pada $\hat{Y}=16,385+0,706 \mathrm{X}_{1}+$ $0,851 \mathrm{X}_{2}$.

Hasil penelitian yang didapat sejalan dengan hasil penelitian ini sejalan dengan Firda 2013 yang menyatakan responsibilitas dan sikap kerja merupakan dua faktor yang menentukan keberhasilan pegawai dalam melaksanakan pelayanan. Namun pelaksanaan penelitian Firda mempergunakan metode kualitatif dengan teknik penentuan informan snowball sampling serta mempergunakan teknik pengumpulan data melalui wawancara dan dokumentasi. Hal ini menunjukkan adanya perbedaan dengan proses penelitian dari penggunaan metode peneliti.

\section{SIMPULAN DAN SARAN Simpulan}

Simpulan Pengaruh Responsibilitas dan Sikap Kerja secara bersama-sama 
terhadap Kualitas Pelayanan di Kelurahan Tengah Kecamatan Cibinong Kabupaten Bogor sebagai berikut :

1. Terdapat pengaruh positif dan signifikan Pengaruh Responsibilitas terhadap Kualitas Pelayanan di Kelurahan Tengah Kecamatan Cibinong Kabupaten Bogor. Besarnya pengaruh Responsibilitas terhadap Kualitas Pelayanan di Kelurahan Tengah Kecamatan Cibinong Kabupaten Bogor sebesar $67,9 \%$.

2. Terdapat pengaruh positif dan signifikan Sikap Kerja terhadap terhadap Kualitas Pelayanan di Kelurahan Tengah Kecamatan Cibinong Kabupaten Bogor. Besarnya pengaruh Sikap Kerja terhadap Kualitas Pelayanan di Kelurahan Tengah Kecamatan Cibinong Kabupaten Bogor sebesar $67,5 \%$.

3. Terdapat pengaruh positif dan signifikan Pengaruh Responsibilitasdan Sikap Kerja secara bersama-sama terhadap Kualitas Pelayanan di Kelurahan Tengah Kecamatan Cibinong Kabupaten Bogor. Besarnya Pengaruh Responsibilitasdan Sikap Kerja secara bersama-sama terhadap Kualitas Pelayanan di Kelurahan Tengah Kecamatan Cibinong Kabupaten Bogor sebesar 76,6\%.

\section{Saran}

Saran-saran untuk meningkatkan Kualitas Pelayanan di Kelurahan Tengah Kecamatan Cibinong Kabupaten Bogor, yaitu: 1. Kepada Lurah di Kelurahan Tengah Kecamatan Cibinong Kabupaten Bogor, disarankan:

a. Melakukan upaya responsibilitas diterapkan kepada setiap aparat yang ada di Kelurahan Tengah Kecamatan Cibinong Kabupaten Bogor dengan cara melaksanakan penegakan aturan kerja pada pegawai dalam memberikan layanan kepada masyarakat.

b. Melakukan upaya peningkatan sikap kerja melalui pembinaan etika pegawai dalam memberikan sikap keramahan dalam melayani.
2. Kepada Pegawai di Kelurahan Tengah Kecamatan Cibinong Kabupaten Bogor, disarankan:

a. Melakukan upaya peningkatan responsibilitas dalam bekerja memberikan pelayanan kepada masyarakat khususnya di Kelurahan Tengah Kecamatan Cibinong Kabupaten Bogor.

b. Melakukan upaya peningkatan sikap kerja melalui kejujuran dalam melaksanakan tugas dengan tidak menerima pungutan pada setiap aktivitas pelayanan di Kelurahan Tengah Kecamatan Cibinong Kabupaten Bogor.

\section{DAFTAR PUSTAKA}

Achmad, Mansyur. 2011. Teori-Teori Mutakhir Administrasi Publik. Yogyakarta: Mahakarya Rangkang Offset.

Anggara, Sahya. 2012. Ilmu Administrasi Negara. Bandung: Pustaka Setia.

Dwiyanto, Agus. 2006. Mewujudkan Good Governance Melalui Pelayanan Publik, Yogyakarta: Gadjah Mada University Press.

Hardiansyah, 2011. Kualitas Pelayanan Publik. Yogyakarta: Gava Media.

Keban, Yeremias T, 2008, Enam Dimensi Strategis Administrasi Publik:

Konsep, Teori, dan Isu, Edisi Kedua. Cetakan Pertama. Yogyakarta: Penerbit Gaya Media.

Latunreng. Wahyudin, 2010, Manajemen Sumber Daya Manusia, Jakarta: IPPSDM-WIN.

Luthans, Fred. 2006. Perilaku Organisasi. Penerjemah Vivin Andhika Yuwono, Shekar Purwanti, Th. Arie P, Winong Rosari. Yoyakarta: Andi.

Moenir. H.A.S, 2006, Manajemen Pelayanan Umum, Jakarta: PT. Bumi Aksara.

Napitupulu, Paimin. 2007. Pelayanan Publik \& Customer Satisfaction. Bandung: Alumni.

Ndraha, Taliziduhu. 2003. Kbybernology: Imu Pemerintahan Baru. Jakarta: Rineka Cipta. 
Pasolong, Harbani. 2010. Teori Administrasi Publik. Bandung: Alfabeta.

Ratminto, Atik Septi Winarsih, 2010, Manajemen Pelayanan, Jakarta: Pustaka Pelajar.

Rivai, Veithzal, Deddy Mulyadi. 2012. Kepemimpinan dan Perilaku Organisasi. Jakarta: PT. Rajagrafindo Persada.

Robbins, Stephen P, 2006. Perilaku Organisasi, Jakarta: PT. INDEKS Kelompok Gramedia.

Safroni, M. Ladzi. 2012. Manajemen dan Reformasi Pelayanan Publik. Yogyakarta: Aditya Media Publishing.

Siagian, Sondang P. 2008. Filsafat Administrasi, Edisi Revisi, Jakarta: Bumi Aksara.

Sinambela, Lijan Poltak. 2008. Reformasi Pelayanan Publik. Jakarta: PT. Bumi Aksara.

Sugandi, Yogi, Suprayogi. 2011. Administrasi Publik: Konsep dan Perkembangan Ilmu Indonesia. Yogyakarta: Graha Ilmu.

Syafiie, Inu Kencana. 2011. Pengantar Ilmu Pemerintahan (Edisi Revisi). Bandung: Refika Aditama.

Syafri, Wirman. 2012.Studi tentang Administrasi Publik. Jakarta: Erlangga.

Tachjan. 2008. Implementasi Kebijakan Publik. Bandung: AIPI.

Thoha, Miftah. 2011. Ilmu Administrasi Publik Kontemporer. Jakarta: Kencana.

Umam, Kaherul. 2012. Manajemen Organisasi. Bandung: Pustaka Setia.

Wibawa, Samodra. 2005. Reformasi Administrasi, Cetakan Pertama, Yogyakarta: Gava Media.

Winardi. J. 2005. Manajer dan Manajemen. Bandung: Citra Aditya Bakti.

\section{Peraturan dan Perundang-Undangan}

Undang-undang Nomor 25 tahun 2009 tentang Pelayanan Publik.

Undang-undang Nomor 32 tahun 2004 tentang Pemerintahan Daerah.

Peraturan Pemerintah Nomor 73 Tahun 2005 tentang Kelurahan.

\section{Dokumen}

Firda, Falakhul, 2013. Administratif Responsibility, Studi Deskriptif tentang Perilaku Kerja Pegawai pada Pelayanan Publik dalam Perspektif Administrative Responsibility di Dinas Kependudukan dan Catatan Sipil Kota Surabaya, Jurnal Kebijakan dan Manajemen Publik. ISSN 2303341X, Volumen I, Nomor I, Januari 2013.

http://journal.unair.ac.id/filerPDF

/Falakhul\%20Firda.pdf. Diunduh Selasa, 09 Juni 2015.

Hidayati, Tri Susila, 2011. Pengaruh Komunikasi, Sumber Daya, Sikap Pelaksana, dan Struktur Birokrasi terhadap Kualitas Pelayanan Pendidkan RSMABI di SMA N 1 Kota Tegal. Perpustakaan Digital Universitas Terbuka. Program Pascasarjana Universitas Terbuka Jakarta. http://www.pustaka.ut.ac.id. Diunduh Selasa, 17 Februari 2015

Pribadi, Teguh, Leonardo Budi Hasiholan, Andi Tri Haryono. 2014. Pengaruh Kinerja Aparatur Terhadap Kualitas Pelayanan Publik Pada Biro Umum Sekretaris Daerah Profinsi Jawa Tengah. Sosioekotekno Jurnal ilmiah mahasiswa unpand, Fakultas Ekonomi Universitas Pandanaran Semarang, Edisi 2014 Vol. 2. http://jurnalsosioekotekno.org/article/. ISSN 23377003. Diunduh 17 Februari 2015 